\title{
California Climate Action Planning Conference 2013
}

\author{
Michael Boswell \\ AICP; professor, CRP, Cal Poly.
}

The Cal Poly College of Architecture \& Environmental Design in partnership with the Governor's Office of Planning and Research (OPR) hosted the inaugural California Climate Action Planning Conference on Thursday, January 31 and Friday, February 1, 2013 on campus. The conference was attended by over 200 professionals working in the public, private, and nonprofit sectors on climate change and sustainability.

This was the first conference to focus solely on the practice of local and regional climate action planning in California. It featured in-depth presentations and discussions on both technical and political facets of climate action planning and featured experts and practitioners from around the state. Sessions addressed a variety of topics including GHG inventories, climate mitigation and adaptation, public participation, implementation and financing, and emerging challenges. Conference presentations are available at http:// digitalcommons.calpoly.edu/ccapc/2013/

The timing of the conference was opportune. The week before both President Obama and Governor Brown gave major speeches on climate change. In his Inaugural Address, President Obama made clear the ethical obligation to address climate change when he said: "We will respond to the threat of climate change, knowing that the failure to do so would betray our children and future generations."

Governor Jerry Brown stated the urgency of climate change problem: "When we think about California's future, no longterm liability presents as great a danger to our well-being as the buildup of carbon dioxide and other greenhouse gases in the atmosphere."

Michael McCormick, Local and Regional Affairs Policy Advisor and Senior Planner, Governor's Office of Planning \& Research linked these calls to action with the conference: "California is a national and international leader in the field of climate action planning and this conference brings together the best professionals in the field to share their collective knowledge."

The conference was kicked of by introductory remarks from Cal Poly President Dr. Jeffrey Armstrong and College of Architecture and Environmental Design Dean, Dr. Christine Theodoropoulos. Dr. Armstrong talked about actions taken by Cal Poly to reduce the campus carbon footprint including aggressive water conservation practices, LEED-certified new buildings, and heating/cooling efficiency upgrades. He concluded with wishes for the conference attendees: "Please enjoy. Please learn. And then let's put in all into action." See more about Cal Poly sustainability successes at: http://afd. calpoly.edu/sustainability/

The keynote speaker was Henry Hilken, Director of Planning and Research at the Bay Area Air Quality Management District. Mr. Hilken spoke about the need to maintain the environmental progress that has been made in addressing air pollution in California.

Sponsors included PG\&E, PMC, Bay Area Air Quality Management District, Ascent Environmental, California Chapter of the American Planning Association, SIP/Central Coast Vineyard Team, San Luis Obispo County Air Pollution Control District, and ESA.

The Steering Committee for the conference included Matt Burris, Raimi \& Associates; Jeff Henderson, PMC; Michael McCormick, Governor's Office of Planning \& Research; lan Peterson, Bay Area Air Quality Management District; Jillian Rich, PG\&E; Honey Walters, Ascent Environmental; The Cal Poly CRP conference team included Michael R. Boswell, Ph.D., AICP, Conference Director; Adrienne I. Greve, Ph.D., Assistant Conference Director; Jean Long, MCRP '13, Student Coordinator; Stevie Schmidt, MCRP'14, Student Assistant; Alice Zanmiller, BSCRP'15, Student Assistant.

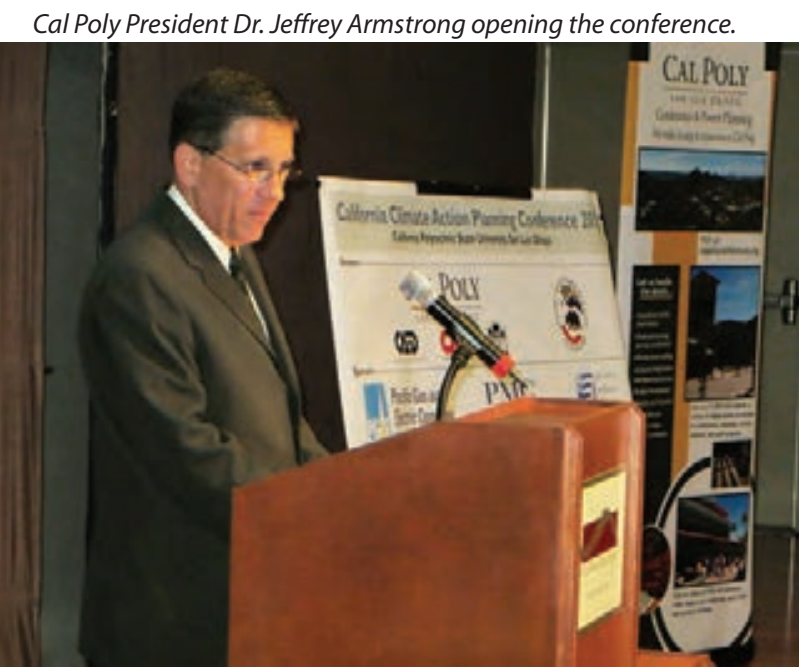

